\title{
VIEWPOINT
}

\section{Managing water to enhance global cereal yields}

\author{
B.A. Stewart and Rattan Lal
}

D ata show a strong world dependence on cereals for food (table 1). To meet the needs of a population reaching 9.8 billion by 2050 , annual cereal production would need to increase by almost $1 \times$ $10^{9} \mathrm{Mg}\left(1.1 \times 10^{9} \mathrm{tn}\right)$ and meat production by over $2 \times 10^{8} \mathrm{Mg}\left(2.2 \times 10^{8} \mathrm{tn}\right)$ (Alexandratos and Bruinsma 2012). Rask and Rask (2011) stated that the dynamics of economic development in developing countries, particularly China and India, is perhaps the dominant factor affecting world food needs in the immediate future. They estimated that "a stable per capita diet at high income levels requires five to seven times more agricultural resources to produce than does a predominantly cropbased diet at low income levels" (Rask and Rask 2011.)

Lal (2016a) suggested that the cereal grains needed to feed the 11 billion people projected for 2100 could be produced on $5 \times 10^{8}$ ha $\left(1.2 \times 10^{9} \mathrm{ac}\right)$. He concluded that "rather than expanding the area under cropland, agriculturally marginal and degraded soils can be set aside for nature conservancy." He stated that to achieve this goal, the global average cereal yield of $3.27 \mathrm{Mg} \mathrm{ha}^{-1}\left(1.46 \mathrm{tn} \mathrm{ac}^{-1}\right)$ in 2005 can be increased to $5 \mathrm{Mg} \mathrm{ha}^{-1}\left(2.23 \mathrm{tn} \mathrm{ac}^{-1}\right)$ by 2050, $6 \mathrm{Mg} \mathrm{ha}^{-1}$ (2.68 tn ac ${ }^{-1}$ ) by 2080, and $7 \mathrm{Mg} \mathrm{ha}^{-1}$ (3.12 $\mathrm{tn} \mathrm{ac}^{-1}$ ) by 2100 through sustainable intensification of agroecosystems in sub-Saharan Africa, South Asia, and the Caribbean by a widespread adoption of site-specific best management practices (Lal 2016a).

Cereal production will remain a critical issue in the future. Alexandratos and Bruinsma (2012) reported that cereals continue as the most important source of food, and they made their projection that $3.009 \times 10^{9} \mathrm{Mg}\left(3.316 \times 10^{9} \mathrm{tn}\right)$ of cere-

B.A. Stewart is a distinguished university professor of soil science at the West Texas A\&M University, Canyon, Texas. He is also the director of the Dryland Agriculture Institute. Rattan Lal is a distinguished university professor of soil science and the director of the Carbon Management and Sequestration Center at the Ohio State University, Columbus, Ohio. als would be needed in 2050 based on the 2005 to 2007 population and cereal production data. The purpose of this paper is to evaluate opportunities for meeting the projected demands for cereal production by 2050 and 2100 and estimate the amount of cropland that will be required.

\section{CROPLAND RESOURCES}

In 1961 , there were $4.9 \times 10^{9}$ ha $(1.2$ $\times 10^{10} \mathrm{ac}$ ) of agricultural land of which $1.293 \times 10^{9}$ ha $\left(3.195 \times 10^{9} \mathrm{ac}\right)$ were cropland. In 2014, agricultural land area had decreased to $4.457 \times 10^{9}$ ha $(1.101$ $\left.\times 10^{10} \mathrm{ac}\right)$, but cropland had increased to $1.417 \times 10^{9}$ ha $\left(3.501 \times 10^{9} \mathrm{ac}\right)$ (FAOSTAT 2017). Alexandratos and Bruinsma (2012) reported that arable land area in developed countries peaked in the late 1960s, remained stagnant until about the mid-1980s, and then started to decline. Therefore, with arable land scarce in many developing countries, Alexandratos and Bruinsama (2012) concluded that more and more of the wheat (Triticum aestivum L.) and rice (Oryza sativa L.) production in developing countries will have to come entirely from gains in yields, and the yield increases in many countries will also have to compensate for a decline in areas allocated to these crops. As a result, they projected between 2005 to 2007 and $2050,90 \%$ of increased production will have to come from higher yields and more intensive use of land.

Alexandratos and Bruinsma (2012) reported that worldwide, irrigated agri-

\section{Table 1}

Kilocalories per capita per day from various sources for world population (National Geographic 2014).

\begin{tabular}{lrrr}
\hline Year & $\mathbf{1 9 6 1}$ & $\mathbf{1 9 8 5}$ & $\mathbf{2 0 1 1}$ \\
\hline Total & 2,194 & 2,589 & 2,870 \\
Grain & 1,085 & 1,310 & 1,296 \\
Produce & 270 & 240 & 327 \\
Dairy and eggs & 207 & 215 & 235 \\
Meat & 132 & 193 & 272 \\
Sugar and fats & 345 & 485 & 570 \\
Other & 155 & 146 & 170
\end{tabular}
use and accounts for $44 \%$ of all crop production and $42 \%$ of cereal production, and that approximately $2 \times 10^{7}$ ha $\left(5 \times 10^{7}\right.$ ac $)$ new irrigated area will be added by 2050 with essentially all being in developing countries. Renner (2012) and Siebert et al. (2015) estimated approximately 20\% of arable land is irrigated. From 1961 to 2005 through 2007, world area equipped for irrigation increased from about $1.45 \times$ $10^{8}$ ha $\left(3.58 \times 10^{8} \mathrm{ac}\right)$ to about $3 \times 10^{8} \mathrm{ha}$ $\left(7.41 \times 10^{8} \mathrm{ac}\right)$.

Increased yields must also occur on rainfed lands to meet the expected demands for cereals and other crops. However, rainfed land in developed countries will decrease about 7\% while both irrigated and rainfed land areas in developing countries will increase approximately 10\%. About 20\% of the arable land in developing countries will be irrigated in 2050, which is very close to the percentage irrigated in 2005 to 2007 . Therefore, it is critical that crop yields be increased on the $80 \%$ of cropland that relies entirely on precipitation.

\section{CONSTRAINTS FOR INCREASING YIELDS}

The worldwide average grain yields (GY) in 2014 for maize (Zea mays L.), paddy rice, and wheat were $5,616,4,557$, and $3,307 \mathrm{~kg} \mathrm{ha}^{-1}(5,009,4,065$, and 2,950 $\mathrm{lb} \mathrm{ac}^{-1}$ ), respectively. The main factor that determines GY is the amount of water that is transpired through the plant leaves (figure 1). More importantly, increasing the amount of water used by transpiration culture covers $16 \%$ of the arable land in 


\section{Table 2}

Projected areas of arable land, rainfed land, and irrigated land in 2050 compared to the amounts in 2005 to 2007 (Alexandratos and Bruinsma 2012).

\begin{tabular}{|c|c|c|c|c|c|c|}
\hline \multirow[b]{2}{*}{ Area } & \multicolumn{2}{|c|}{ Arable land (ha) } & \multicolumn{2}{|c|}{ Rainfed land (ha) } & \multicolumn{2}{|c|}{ Irrigated land (ha) } \\
\hline & $2005 / 2007$ & 2050 & $2005 / 2007$ & 2050 & $2005 / 2007$ & 2050 \\
\hline Developed countries & $6.24 \times 10^{8}$ & $5.86 \times 10^{8}$ & $5.69 \times 10^{8}$ & $5.30 \times 10^{8}$ & $5.6 \times 10^{7}$ & $5.6 \times 10^{7}$ \\
\hline
\end{tabular}

(T) affects other factors, so the cumulative effect becomes greater with each increased amount. Doubling the amount of water transpired can often, as a minimum, quadruple GY.This is why even small amounts of irrigation water can increase GYs dramatically. Without question, water is the main worldwide constraint for wheat and maize production. Although irrigated land area in developing countries is expected to increase about $10 \%$ by 2050 , it will still be only about $20 \%$ of the worldwide arable land compared to $21 \%$ in 2005 to 2007 (table 2). In sub-Saharan Africa, however, where food needs are great, land equipped for irrigation was only $6 \times 10^{6}$ ha $\left(1.5 \times 10^{7} \mathrm{ac}\right)$ in 2005 to 2007 , and the area is anticipated to only increase to $7 \times$ $10^{6}$ ha $\left(1.7 \times 10^{7} \mathrm{ac}\right)$ by 2050 .

Rainfed agriculture is practiced on about $80 \%$ of the world's cropland and accounts for about $60 \%$ of crop production. It is the dominant system in most of the developing countries and accounts for $97 \%$ of the staple production in sub-Saharan Africa (FAO 2011) where cereal yields

\section{Figure 1}

Factors of grain yield (Stewart and Peterson 2015).

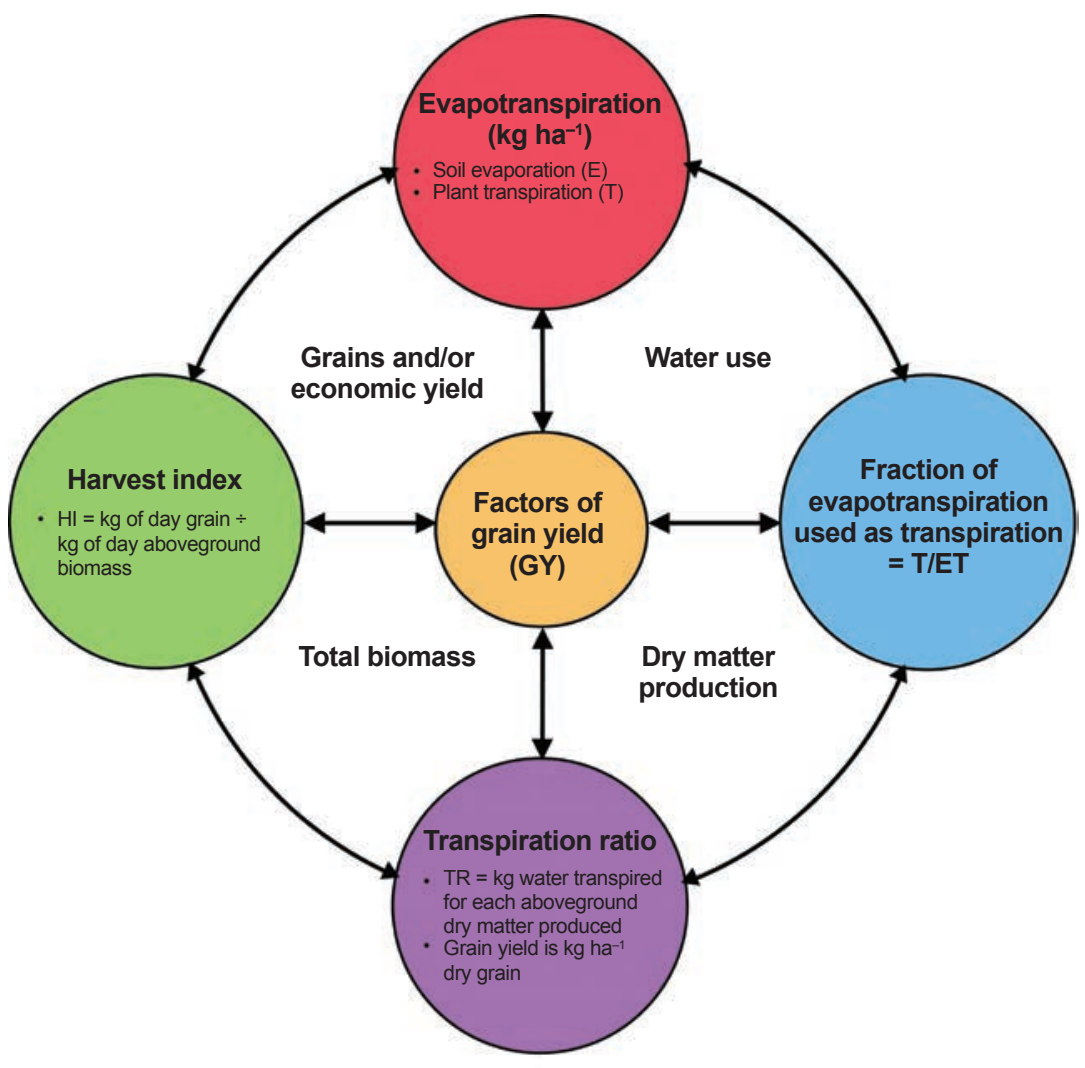

$G Y=E T \times(T \div E T) \times(1 \div T R) \times H I$ have changed little since the 1960s, which has resulted in a doubling of the cultivated cereals cropland. Rainfed maize yields, for example, have remained constant at around $1 \mathrm{Mg} \mathrm{ha}^{-1}$ (0.45 th $\mathrm{ac}^{-1}$ ) (FAO 2011). When water is the primary constraint, the only way that yield can be increased is to increase the amount of water transpired, and this becomes increasingly difficult in semiarid regions. Molden (2007) reported that "evidence from farms worldwide shows that less than $30 \%$ of rainfall is used by plants in the process of biomass production. The rest evaporates into the atmosphere, percolates to groundwater, or contributes to river runoff." Therefore, the water productivity (WP) values increase with increasing evapotranspiration (ET), and the maximum is always at the maximum yield level and the minimum is always at the point that just exceeds the threshold value. This is because the proportion of ET that is required to initiate grain production becomes smaller as ET becomes greater. Increasing WP in dryland, by enhancing ET and conserving soil water in the rootzone, is the key strategy to advance food security.

\section{POTENTIAL YIELD}

Fischer et al. (2014) defined potential yield (PY) as "the yield to be expected with the best-adapted variety with the best management of agronomic and other inputs, and in the absence of manageable abiotic and biotic stresses." This implies that the yield will continue to increase with time until PY is reached, and the projected increase will occur through improved agronomy and varieties.

The only way that GY will not plateau is for the PY to continually increase. Fischer et al. (2014) conducted a thorough review of worldwide data of crop yields and discussed the relative role of plant breed- 
ing versus that of soil management and agronomy. Improving soil health, which is severely degraded in croplands of the developing countries, is an important option. Improving soil health, through increase in soil organic matter (Lal 2016b, 2017), would also advance the Sustainable Development Goals (SDGs) of the United Nations, especially SDG \#1 (no poverty) and SDG \#2 (zero hunger) by 2030. Fischer et al. (2014) stressed that water-limited PY is dependent on the amount of water transpired, the $\mathrm{T}$ efficiency, and the harvest index (HI). If water is the limiting factor, then ET will be the limiting factor, and the other factors will be affected accordingly.

Since the early 1970 s, there has been increased use of conservation agriculture (CA), reduced tillage, and no-till systems that have sometimes enhanced the amount of ET, increased the ET used as $\mathrm{T}$ (T/ET) factor by reducing evaporation from the soil surface, and improved microclimate-all of which tend to increase GYs. Therefore, agronomic practices that have improved water storage and use as T, along with improved fertilizer and pesticide practices, may have had a much larger influence on yields in many cases than improved varieties as suggested by Fischer et al. (2014). Even they, however, stated that "there would be future incremental changes in agronomic technologies that cannot be ignored because past agronomic innovations have historically surprised forecasters."

The most important factor is ET, which for rainfed systems is limited to the amount of growing season precipitation plus the amount of plant available soil water stored in the soil at time of seeding used during the growing season. If adequate irrigation water is available to supplement precipitation, the amount of ET will be limited by climatic conditions or by the crop species and the length of maturity of the specific variety used. When the amount of ET is low, so GY will be low. Therefore, the only way to significantly increase GY is to increase ET. Improved cultivars and fertilizers are required for high yields, but they are of little or no benefit unless one of them is more limiting than water.

\section{INCREASING YIELDS IN LOW PRECIPITATION REGIONS}

Since GY can only be increased significantly in low precipitation regions by increasing ET, feasible solutions are limited and challenging. Whenever feasible, irrigation is the best choice because it eliminates risk and greatly increases yield. Expansion of irrigation is becoming increasingly costly because all the easily obtainable water resources have already been developed. Also, salinity problems and declining water tables are causing increasing amounts of irrigated lands to be abandoned every year so the rate of irrigation expansion is slowing. Therefore, rainfed systems must become more productive. Worldwide, CA is being promoted as a system that will increase productivity at the same time it improves soil health and makes the system more sustainable. However, in areas of low precipitation and high average temperatures, implementing the three principles of CA is difficult.

Water harvesting can be a successful technology in dryland areas where irrigation water is lacking and growing season precipitation is insufficient in most years for dependable crop production. It is often more feasible for smallholder farmers than for farmers with large cropland areas. Oweis et al. (2012) summarize many of the studies conducted worldwide and offer suggestions and guidelines for successful water harvesting systems.

Successful production of cereal grains in low precipitation becomes increasingly more difficult with each doubling in the amount of ET, which is largely dependent on growing season successive decrease in precipitation. Therefore, the first priority in low precipitation areas is to manage the precipitation and prevent runoff. The second priority is to minimize evaporation from the soil surface, and this is mostly accomplished by reducing soil disturbance and keeping the soil covered with crop residues or living plants. The only water that increases yield is the water transpired through the leaves of the target crop. While the crop variety is important as well as having adequate soil fertility, these are impor- tant only as they affect one of the factors that are strictly water dependent.

\section{PRODUCING CEREALS ON LIMITED CROPLAND RESOURCES}

The amount of cereal grain required in 2050 will certainly be significantly greater, but how much greater will depend not only on the increase in world population, but more importantly on the growing prosperity of the developing countries. Alexandratos and Bruinsma (2012) estimated the cereal grain demand in 2050 as $3.009 \times 10^{9} \mathrm{Mg}\left(3.316 \times 10^{9} \mathrm{tn}\right)$ based on 2006 to 2007 data. There seems little doubt that the demand for cereal grains can be met by growing them on $5 \times 10^{8}$ ha $\left(1.2 \times 10^{9} \mathrm{ac}\right)$. Between 1961 and 2014 , rice yields have increased about 2.5 times, while wheat and maize yields have roughly tripled. However, even though it appears that cereal grain demand could almost certainly be met with using no more than $5 \times 10^{8}$ ha of cropland, or even less, for this to happen will also require a strong policy intervention and judicious governance, especially in developing countries. Also, essentially all of the increased population by 2050 will be in the developing countries, and these are also the countries where increasing prosperity will increase the demand for animal-based protein that increases the grain demand for animal feed. Increase in production of food legumes and pulses is an important strategy to improve the protein nutrition while also reducing the demand for nitrogen $(\mathrm{N})$ (Lal 2017).

\section{SUMMARY AND CONCLUSIONS}

Based on increasing yield trends since 1961 for maize, rice, and wheat-crops that account for $90 \%$ of cereal grains production-sufficient amounts to meet the 2100 demand could be produced on $5 \times 10^{8}$ ha $\left(1.2 \times 10^{9} \mathrm{ac}\right)$ or even less. However, cereal grains will continue to be grown on marginal soils in low precipitation areas even though yields and WP values are low. Grain yields have and will continue to increase in these areas but to a limited degree because of low and highly variable precipitation amounts. Soil health is determined by many factors but largely depends on the amount of organic carbon 
(C), which is dependent on how much biomass is produced; biomass is in turn dependent on how much water is transpired by plants.

Worldwide GYs will continue to increase but at a declining rate compared to the past few decades. Presently, GYs are increasing at a faster rate in developing countries because they were slower in developing irrigation and improving water management practices than developed countries. Increasing GYs in areas of limited precipitation can happen only with increasing the amount of ET by adding irrigation water where feasible, and by improving the precipitation WP values by adopting CA.

\section{REFERENCES}

Alexandratos, N., and J. Bruinsma. 2012. World agriculture towards 2030/2050. ESA Working Paper No. 12-03. Rome: Food and Agriculture Organization of the United Nations. http:// www.fao.org/fileadmin/templates/esa/Global_ persepctives/world_ag_2030_50_2012_rev.pdf.

FAO (Food and Agriculture Organization of the United Nations). 2011. The State of the World's Land and Water Resources for Food and Agriculture. Rome: Food and Agriculture Organization of the United Nations. http:// www.fao.org/docrep/017/i1688e/i1688e.pdf.

FAOSTAT. 2017. Food and Agriculture Data. Rome: Food and Agriculture Organization of the United Nations. http://www.fao.org/faostat/ en/\#home.

Fischer, T., D. Byerlee, and G. Edmeades. 2014. Crop yields and global food security:Will yield increase continue to feed the world? ACIAR Monograph No. 158. Canberra: Australian Centre for International Agricultural Research.

Lal, R. 2016a. Feeding 11 billion on 0.5 billion hectare of area under cereal crops. Food and Energy Security 239-251, doi:10.1002/fes3.99.

Lal, R. 2016b. Soil health and carbon management. Food and Energy Security 5(4):212-222.

Lal, R. 2017. Improving soil health and human protein nutrition by pulses-based cropping systems. Advances in Agronomy 145:167-204

Molden, D. (ed.). 2007. Water for food, water for life. Comprehensive assessment of water man- agement in agriculture. Colombo/London: IWMI/Earthscan. http://www.iwmi.cgiar.org/ assessment/.

National Geographic. 2014. What the world eats. http://www.nationalgeographic.com/ what-the-world-eats/.

Oweis, T., D. Prinz, and A. Hachum. 2012. Rainwater harvesting for agriculture in the dry areas. London: CRC Press, Taylor and Francis Group.

Rask, K.J., and N. Rask. 2011. Economic development and food production-consumption balance: A growing global challenge. Food Policy 36:185196, doi:10.1016/foodpoi.2010.11.015.

Renner, Judith. 2012. Global irrigated area at record levels, but expansion slowing. Washington, DC: Worldwatch Institute. http://www.worldwatch. org/global-irrigated-area-record-levels-expansion-slowing-0.

Siebert, S., M. Kummu, M. Porkka, P. Döll, N. Ramankutty, and B.R. Scanlon. 2015. A global data set of the extent of irrigated land from 1900 to 2005. Hydrology and Earth System Science 19:1521-1545.

Stewart, B.A., and G.A. Peterson. 2015. Managing green water in dryland agriculture. Agronomy Journal 107:1544-1553, doi:10.2134/ agronj14.0038. 